\title{
EFL Students Perspective towards Online Learning Barriers and Alternatives Using Moodle/Google Classroom during COVID-19 Pandemic
}

\author{
Like Raskova Octaberlina ${ }^{1} \&$ Afif Ikhwanul Muslimin ${ }^{2}$ \\ ${ }^{1}$ Department of English Language Education, Universitas Islam Negeri Maulana Malik Ibrahim Malang, Jalan \\ Gajayana 50 Malang, East Java, Indonesia \\ ${ }^{2}$ Department of English Language Education, Universitas Islam Negeri Mataram, Jalan Gajahmada 100 Jempong \\ Baru, Mataram, West Nusa Tenggara, Indonesia \\ Correspondence: Like Raskova Octaberlina, Department of English Language Education, Universitas Islam Negeri \\ Maulana Malik Ibrahim Malang, Jalan Gajayana 50 Malang, East Java, Indonesia.
}

Received: July 25, 2020

Accepted: August 10, 2020

Online Published: August 12, 2020

doi:10.5430/ijhe.v9n6p1

URL: https://doi.org/10.5430/ijhe.v9n6p1

\begin{abstract}
Covid-19 pandemic has made many countries adapt to new situations in different sectors including education. The Indonesia government has decided to adjust the education mode from face-to-face to online meetings using various learning management systems (LMS) such as moodle and google classroom. Moreover, the present research depicted the online learning barriers faced by students as well as their alternatives to cope them. The research implemented a descriptive mixed-method survey design. The participants were 25 students from the English Education Department. The instruments used to gather the data were the questionnaires and interviews regarding the topics. The results showed that students experienced three barriers during online learning including unfamiliarity of e-learning, slow internet connection, and physical condition e.g., eye strain. The alternatives they proposed were providing training to implement the LMS before the real class, converting high-definition or big-size files into smaller ones, and giving break during the online class. The conclusion stated that students had to be creatives to find any solutions and innovations regarding learning barriers including maintaining good communication with teacher and understanding the best learning styles individually.
\end{abstract}

Keywords: online learning, students' perspectives, pandemic, EFL, LMS

\section{Introduction}

The World Health Organization (WHO) proclaimed COVID-19 as a worldwide crisis on January 30th, 2020, and a worldwide pandemic on March 11th, 2020. As of now, COVID-19 is influencing 213 nations and regions (WHO, 2020). As a response to COVID-19, most nations have applied severe social separating measures and a lockdown strategy. Clearly, this pandemic has tremendously affected schools, understudies, and educators. As of March twelfth, 2020, 46 nations in five distinct landmasses have announced school terminations and 26 of these nations have completely shut schools across the country (Huang, Liu, Tlili, Yang, and Wang, 2020). In Indonesia, the Government has confined network preparation trying to forestall the spread of the ailment and continues advancing a plan of telecommuting, concentrate from home and love at home. Schools and Higher Education Institutions (HEIs) in Indonesia have been incidentally shut since March fourteenth, 2020. To manage schools and HEIs terminations in Indonesia, the instructing and learning process has been kept up distantly utilizing Information and Communication Technologies (ICT). Due to the impact of the coronavirus (Covid-19), the government requires learning to be implemented by distance learning, teachers teach from home, face-to-face learning in schools are stopped, students are not coming to the school and teachers work from home.

In Indonesia, distance learning is not something new, since the adoption of technology in education and learning, efforts to educate the Indonesian people have been carried out with this distance learning, the reasons underlying state attitudes to applying it is because of the geographical location and the archipelago as well the extent of Indonesia compared to other countries. Distance learning is an interactive effort to learn to use the network internet and computer as learning facilities. 
The transformation of computerized innovation has a positive impact on the different day-today exercises of human lives. Aside from different areas, the instruction segment advancing instructing learning exercises is additionally impacted in a major manner. The customary teaching method has experienced a progressive change in light of the jumping changes of Information, what's more, Communication Technologies (ICTs) in the most recent decades. The progressing changes in computerized innovation offer enormous possibilities for different parts like mechanical segments, clinical divisions, banking areas, instruction segments, and so forth for improving the expectations for everyday comforts. Modern areas are enthusiastic about overhauling their human abilities through different web-based preparing programs. Internet teaching classes help them to obtain a lot required abilities for achieving higher profitability in their separate fields. In a decade ago of the twentieth century, colleges are significantly more affected because of computerized innovation and reinforcing for 'Teacher'. Positive advancements in Internet and media transmission innovations have evacuated the hindrances of time, separation, place, and so forth. Moreover, gives a lot of recreation in educating learning exercises. There are emotional changes in the learning condition. These days, colleges around the globe endeavor to take the most extreme advantage out of the innovative upsets and give a superior instructing learning condition for different partners. Students, teachers, and organizations are generally profited in the carefully associated world.

The utilization of technology improves the quality degree of learning and teaching among the partners. For this progressing research reason, the E-Learning term is characterized as, "inventive way to deal with training conveyance by means of electronic types of data that upgrade the Students' aptitudes, information, or other learning execution" [7]. Different researchers characterize the term E-Learning as the utilization of new and present-day Information and Communications Technology (ICT) with the assistance of systems of PCs to give learning materials, teaching, and data to partner [8]. Here partners of the E-Learning frameworks are Students, Instructors, Technical and Administrative staff, and higher specialists of the college [9]. Some different examinations additionally utilized and related different wordings for E-Learning, for example, Online Learning, Online Education, E-Education, and Distance and open learning.

Electronic learning (E-Learning) has been viewed as the most ideal way to deal with proceed with the teaching and learning process during the pandemic. In Indonesia, the E-Learning stages suggested by the government are RumahBelajar and SPAD. RumahBelajar is a free internet learning platform created by the Ministry of Education and Culture of Indonesia as an elective learning asset for teachers and students. SPADA is an E-Learning stage created by the Ministry of Research, Technology, and Higher Education for HEIs. Notwithstanding that, the Ministry of Education and Culture of Indonesia joined forces with a few web-based learning applications, for example, MejaKita, ICANDO, Ganeca Digital, Kelas Pintar, Quipper School, Ruang Guru, Sekolahmu, Zenius, Cisco Webex, and Pahamify and Google Classroom.

One of the most used E-Learning platforms is Google Classroom. Google Classroom is developed by Google for academic purposes that support a blended learning platform. This application is so simple to use, does not take too many spaces on the smartphone's memory and help teacher and student keep on the lesson's track. The users can create a virtual class where can function as in conventional class but save more time, money, and space. Google Classroom allows teachers to spend more time with their students and less time on the paperwork, and it is now even better. Google's latest announcement brings new functionality to Google Classroom. Included in the new functionality is the ability to add more than one teacher, as well as to preparing for classes in advance as well. As (Janzen, 2014)points out that Google Classroom's design purposefully simplifies the instructional interface and options used for delivering and tracking assignments; communication with the entire course or individuals is also simplified through announcements, email, and push notification.Based on the issues explained in the preceding discussion, two research questions are formulated as the following: what are e-Learning barriers in the EFL learners' perspective and how would the barriers be overcome.

\section{Literature Review}

E-Learning integration in educating and learning is a perplexing phenomenon; thusly, numerous teachers may experience different troubles or difficulties. These troubles are otherwise called 'barriers'(Schoepp, 2005). As indicated by the Oxford Dictionary (2015) a barrier is "a fence or a hindrance that forestalls development or access". Moreover, another meaning of a barrier is offered by Schoepp (2005, p. 2), which is "any condition that gains it hard to make ground or to accomplish a goal". In this investigation,) (Schoepp, 2005) meaning of the barrier was adjusted.

Consolidating E-Learning into traditional teaching is to somehow troublesome task which may run over various kinds of complexities and challenges, these issues are called E-Learning Barriers or Obstacles towards incorporating E-Learning with traditional teaching. After broad reviews on the writing identified with Barriers towards E-Learning, 
it is discovered that numerous specialists arranged E-Learning Barriers or Obstacles into four distinct measurements or topics, to be specific Barriers identified with Students, Barriers identified with teachers, Barriers identified with Infrastructure and Technology, Barriers identified with Institutional Management(Quadri, Muhammed, Sanober, Qureshi, \& Shah, 2017). However, barriers that will be talked about in this research article are limited to students and teachers' barriers on using E-Learning only.

Different classifications for E-Learning integration barriers have been proposed. For example, Ertmer (1999) distinguished two arrangements of barriers, specifically first request, and second request barriers. First request barriers incorporate equipment, access, and specialized help while the second request barriers identify with teaching method, conviction, or individual inclinations. Pelgrum (2001) proposed two characterizations for E-Learning barriers: material and nonmaterial barriers. Material barriers allude to the absence of Information and Communication Technologies (ICT) assets while non-material barriers identify with teachers' information and aptitudes. Balanskat, Blamire, \& Kefala (2006) ordered barriers to educator level, school level, and framework level. Assareh \& Bidokht (2011) arranged E-Learning barriers dependent on four zones they influence: students, educators, teaching plans, and schools. E-Learning barriers identified with students incorporate monetary issues, inspiration, evaluation, detachment from peers, deficient E-Learning abilities and experience, warmth, and social space. E-Learning barriers comprise of different angles, for example, information confinements and evaluation challenges.

Regarding of E-Learning barriers, they envelop vagueness, quality, assets, showing the procedure, and assessment. At long last, barriers faced by schools involve hierarchical and basic elements. Quadri, Muhammed, Sanober, Qureshi, \& Shah (2017) examined barriers influencing E-Learning usage. They mentioned barriers into four regions: students, teachers, curriculum, and school. The examination detailed that the most critical hindrance is foundation and innovation while the least noteworthy is understudies. Their examination indicated that a restricted chance to create E-Learning was the hugest factor that upsets E-Learning execution, while the absence of understudies' ICT aptitudes is the least huge factor. Hadijah \& Shalawati (2017) researched boundaries that educators experienced when utilizing E-Learning. The absence of time to set up an exercise utilizing innovation was a significant test that teachers experienced. Other significant restrictions were the absence of sufficient expert improvement concerning innovation, constrained physical assets, insufficiency of assets, restricted access to innovation, absence of specialized help, capability, and certainty.

In this study, the researcher classified E-Learning integration barriers based on Assareh \& Bidokht (2011) classification, namely, teachers, schools, curriculum, and students. The barriers as far as instructor level barrier included: the absence of teacher certainty (Bingimlas, 2009); teachers' reluctance to change their training (Scrimshaw, 2004; Hew \& Brush, 2007); teachers' absence of comprehension of E-Learning favorable circumstances (Scrimshaw, 2004); teachers' mentalities and convictions to ICT (Hew \& Brush, 2007; Ertmer, 1999); and teachers' information and experience. School-level barriers relate prevalently to equipment and programming accessibility, access to web association, and school strategy. Teachers thought about an ideal opportunity to get ready exercises, course books, and the absence of specialized help as significant barriers (Bingimlas, 2009). Additionally, educational program barriers incorporate jumble between students' appraisals and E-Learning(Hew \& Brush, 2007). Another issue is that the educational program may not bolster innovation-based applications (Hew \& Brush, 2007). Concerning the level barrier, this incorporated students' insufficient E-Learning aptitudes (Assareh \& Bidokht, 2011), student's need access to innovation framework and web association, and students' absence of inspiration to utilize E-Learning. As should be obvious from the writing, barriers to E-Learning can incorporate various both material and nonmaterial issues. Innovation and web availability and absence of an E-Learning educational plan and appraisal apparatuses to adequately assess student development limit what teachers can instruct. Inspiration in learning on the web, trust in utilizing E-Learning innovation, and teachers' perspectives to online guidance sway how and if students will learn. Every one of these barriers should be viewed as when confronted with an occasion, for example, a pandemic that powers teachers and students to promptly conform to an alternate method of instructing and learning.

\section{Method}

\subsection{Types of Research}

This is descriptive mixed-method research that investigates the quantitative and qualitative data from Tadris Bahasa Inggr is EFL learners on the students' perspectives of learning barriers and alternatives to overcome it. The quantitative data was taken from the students' survey by filling the questionnaires and the quantitative data was gathered from their responses on the related topic. 


\subsection{Participants}

The participants consisted of 25 participants (13 males and 12 females) who Tadris Bahasa Inggris EFL learners. Moreover, twenty-five students of the participants are on third (48\%) and fifth semester $(52 \%)$. Most of the participants had at least one year of using Google Classroom as a learning media in their class. Nearly half of the participants $(49.1 \%)$ used a computer/laptop for E-Learning whilst the remaining used mobile/handheld devices. The reason the researcher picks the third and the fifth semester is that they are the more active learning semester than the first and seventh during the pandemic. Further detail of the participants is as below:

Table 1. The Participants Demography

\begin{tabular}{lcc}
\hline \multicolumn{1}{c}{ Factor } & Total of Participants in N & Total of Participants in \% \\
\hline Gender & 13 & $52 \%$ \\
Male & 12 & $48 \%$ \\
Female & & \\
Semester & 12 & $48 \%$ \\
Third Semester & 13 & $52 \%$ \\
Fifth Semester & & \\
Users' E-Learning Experience & 25 & $100 \%$ \\
Google Classroom & 25 & $100 \%$ \\
Moodle & 15 & $60 \%$ \\
Skillshare & 2 & $8 \%$ \\
Coursera & & \\
\hline
\end{tabular}

\subsection{Instruments}

Google Classroom, Survey, and interview is used in this research. Google Classroom's class is used to have students to experience Google Classroom class design so that they will be able to measure the barrier of Google Classroom. Then, the survey is spread to twenty students of Tadris Bahasa Inggris UIN Malang third and fifth semester. The questions for the survey is as below:

Q1: The nature of E-Learning is not impersonal

Q2: E-Learning is less effective than a face-to-face meeting

Q3: I am not comfortable with the lack of interaction with other learners or a trainer

Q4: I have several inabilities to work with computers

Q5: I experience Physical health barriers such as eye strain

Q6: I have a low internet bandwidth

Q7: I have too many distractions, e.g., games, YouTube, etc.

Lastly, an interview is conducted with five students to have researchers identify how do they feel about any barrier they experience in using Google Classroom. As below are the interview questions:

Q1: What do you think are the three main barriers to E-Learning?

Q2: What are your recommendations for addressing these barriers?

\subsection{Data Analysis}

Descriptive and statistical analysis were conducted to answer both research questions. Descriptive analysis will be using the interview as the analysis of the problem. Then, the survey will be used on the statistical analysis. Both results of the analyses are used to answer both research questions.

\section{Findings and Discussion}

This research discussed EFL Students' Perspective towards Online Learning Barriers and Alternatives using Moodle/Google Classroom during COVID-19 Pandemic. Furthermore, the quantitative data regarding students' perspectives on online learning barriers are presented as follows: 
Table 2. The EFL Students' Perspectives on Online Learning Barriers

\begin{tabular}{|c|c|c|c|c|c|}
\hline \multirow[b]{2}{*}{ Q\# } & \multirow[b]{2}{*}{ Statements } & \multicolumn{4}{|c|}{$\mathrm{N}$ of Participants $=25$} \\
\hline & & $\begin{array}{l}\text { Strongly } \\
\text { Disagree }\end{array}$ & Disagree & Agree & $\begin{array}{l}\text { Strongly } \\
\text { Agree }\end{array}$ \\
\hline Q1 & Low internet bandwidth & 0 & $2(8 \%)$ & $11(44 \%)$ & $12(48 \%)$ \\
\hline Q2 & $\begin{array}{l}\text { I have too many distractions, e.g., games, } \\
\text { YouTube, etc. }\end{array}$ & 0 & $1(4 \%)$ & $9(36 \%)$ & $15(60 \%)$ \\
\hline Q3 & $\begin{array}{l}\text { Google Classroom do not have a personal touch, } \\
\text { e.g., interactions between learners and teachers }\end{array}$ & 0 & $2(8 \%)$ & $10(40 \%)$ & $13(52 \%)$ \\
\hline Q4 & $\begin{array}{l}\text { Google Classroom is not easy to be accessed } \\
\text { through cellphone }\end{array}$ & 0 & $1(4 \%)$ & $8(32 \%)$ & $16(64 \%)$ \\
\hline Q5 & $\begin{array}{l}\text { I experience physical health barriers such as eye } \\
\text { strain }\end{array}$ & 0 & $3(12 \%)$ & $19(76 \%)$ & $3(12 \%)$ \\
\hline
\end{tabular}

Participants have answered Q1 with the result of $44 \%$ of the respondents (11 respondents) agree to the statement of "Low internet bandwidth". Meanwhile, the rest of $48 \%$ of participants answers strongly agree to the statement, but there is a small amount of the respondents that disagree with the statement (8\%). In Q2, a statement of "I have too many distractions, e.g., games, YouTube, etc." is provided and 4\% of respondents disagree with the statements, and the rest $36 \%$ and $60 \%$ agree and strongly agree to the statements. Q3, "Google Classroom does not have many interactions between learners and teachers", $40 \%$ of the respondents agree to the statement and the rest $52 \%$ strongly agree to the statements, however, there are two participants who disagree with the statement. Q4 has the statement of Google Classroom is not easy to be accessed through a cellphone. $32 \%$ of the respondents agree to the statement, $64 \%$ strongly agree to the statement, and $4 \%$ disagree with the statement. Lastly in Q5, "I experience physical health barriers such as eye strain" is answered by $76 \%$ of the respondents that they agree to the statement. Then, $12 \%$ of the respondents strongly agree, but there are $12 \%$ of the respondents disagree with the statement.

The interview resulted in several responses by five respondents who were interviewed online. Five respondents are asked this question of "What do you think are the three main barriers of E-Learning??" and each of their answers is as below:

Respondent 1:

"Three main barriers of learning English using Google Classroom/online lack internet connection, my eyes hurt a lot when having online learning for too long, one more thing is that Google Classroom does not have real-time interaction"

Respondent 2:

"I think, one is the internet connection because Google Classroom needs a decent connection. Secondly, Google Classroom only gives postings without interaction. Third, I think, YouTube distracts me well",

Respondent 3:

"I have used Google Classroom for more than two semesters. In both semesters, I hate my internet connection"

Respondent 4:

"My cellphone is outdated, therefore Google Classroom is not available to be accessed easily. Even though my wifi is okay, the device is one of the most crucial factors"

Respondent 5:

"Google Classroom is nice to use. Its interface is good but needs a decent internet connection, and that is a bad thing"

This research tried to recognize the key barriers to E-Learning use as apparent by past clients, and the degree to which these barriers sway on a client's goal to utilize E-Learning later on. While past examination has distinguished some possible barriers (frequently in a teaching setting or concentrating on more extensive innovation selection), this investigation gives a one of a kind understanding into the key factors that fill in as barriers to E-Learning especially 
according to students. The research likewise recognized explicitly the degree to which these barriers mean clients are more averse to need to utilize more E-Learning.

Three key elements factors as barriers to e-gaining from the current research. The main factor identified with the idea of E-Learning as a learning approach. This factor incorporates general worries about the legitimacy and viability of E-Learning and the absence of a "personal contact" in contrast with progressively conventional types of learning and improvement. Classroom learning is more personal and interactive, but there are a lot of benefits to conducting in an E-Learning, and most of it is in terms of convenience and affordability, even though "personal contact" cannot be fully acquired as much as in classroom learning (Clover, 2017). It additionally speaks to worry that E-Learning sometimes falls short for some learning styles and speaks to less open door for connection with different students and facilitators. While these recognitions may not all be valid for all types of e-realizing there is little uncertainty that time must be taken to address these worries in the brains of clients if E-Learning is to be effective. While (Cho \& Berge, 2002)recognized a few of the components inside this factor as expected barriers, the current research distinguished this as the most probable factor to affect future E-Learning use and along these lines the most basic to address for fruitful execution.

The second factor relates explicitly to the utilization of technology and the internet. This factor incorporates both ability to utilize technology by the students and the capability of students' internet bandwidth. Internet bandwidth that is needed for Google Classroom is not a small one. Google Classroom has a decent design of the website. Therefore, to load the page, it needs a decent internet connection to use it. That is not the only barrier when a teacher uploads a huge amount of file to the class, it will be hard for students to access it if they do not possess a decent internet connection. Before beginning the course we need to check the student's facilities at their home. It is one of the most significant factors for students to help them in their correspondence. According to (Beschorner, 2020), Indonesia has versatile broadband connections and is slacking behind extensively on the fixed broadband entrance and there are only under $5 \%$ of the populace and about $15 \%$ of families of fixed broadband, meaning that most people would still use data or Mobile Connection to access the internet. This has caused the lack of internet interfaced by the students of E-Learning. Moreover, the cause of this problem is that internet connection is relatively expensive and not everyone is able to purchase a stable one, such as Wi-Fi. Most of the students are still using mobile data which sometimes unstable and relatively expensive as well.

Lastly, the physical barrier is one of the hugest barrier to Google Classroom or E-Learning in general. For most of us, our eyes normally like to concentrate farther than six meters away, so seeing a computer screen represents an outwardly visual task, unlike reading a printed page. The digitally presented page is frequently made out of the littler text, glimmering print, and pixelated pictures. The blend of all these one of a kind qualities and our eyes working more earnestly can frequently prompt trouble focusing on the learning in an E-Learning platform. One of the other factors is the lighting level when utilizing a computer/cellphone. The correct utilization of a PC is about half as bright as that regularly found in a room. Expanded light levels can add to over the top glare and issues related to the adjustment of the eye to various degrees of light (Kozeis, 2009). Unfortunately, in online learning, teachers are not always able to control this problem.

In order to overcome the main three barriers identified above, the researcher proposed several ways for each barrier. Firstly, according to (Pappas, 2015), to create a more personal E-Learning class, the teacher must consider these points, which are:

1) Consider the overall learning goals.

In any event, while making individual learning ways for every student, the objectives and goals of the E-Learning course should in any case be a necessary piece of the E-Learning experience. The way to making an effective individual learning way methodology is to build up an arrangement that consistently mixes the E-Learning course fundamentals with the requirements and needs of every student. Notwithstanding the individualized objectives and targets they set for themselves, they should likewise leave the E-Learning involvement in the key topic.

2) Consider students' various distinctive learning styles.

Not the entirety of your online students have similar individual inclinations or learning styles. This is the reason that it is essential to coordinate a wide scope of online exercises and activities into your E-Learning course, with the goal that your students can pick what works best for them. Auditory students can tune in to virtual talks or digital broadcasts, while visual students can watch E-Learning recordings and view picture rich substance. The individuals who like to peruse their way through an E-Learning course can decide on 
text-based modules. Variety offers each student the chance to profit by the E-Learning course and make a learning way that is obviously appropriate for their necessities.

3) Offer quick feedback.

Despite the fact that an individual learning way is, well, individual students need some type of direction and feedback. On the chance that they complete an online assessment, you should tell them what they have to correct as quickly as time permits with the goal that they do not remember mistaken information or get negative learning practices. The key is to give them the helpful analysis they require, while as yet permitting them to gain from their mistakes. In like manner, you ought to likewise request their criticism with the goal that you can adjust your E-Learning procedure and guarantee that each student is getting the individual help they need.

4) Maintain more interactions

More interactions can be done using other platforms besides Google Classroom. For instance, teachers can use WhatsApp or Line or Telegram in order to connect with their students. If it is available, a zoom conference can also be used to see the students directly face-to-face.

The second barrier is the lack of technology and internet connection. According to (Burns, 2014), High-limit bandwidth speed is critical to basic asset support and protection and updating contents; uploading tasks; working together in shareable documents, etc. Haidkamp (2017) suggests that, in order to cope with this problem, teachers should:

1) Convert video material to audio

The least complex approach to make your classless bandwidth-using is to utilize media designs that expend less transfer speed, for example, sound. E-Learning engineers will in general focus on video and slideshow-style content as the "default" designs for computerized learning, likely in light of the fact that that is the thing that most composing devices are intended for, yet consider for a second what a number of individuals get their news and other data from digital broadcasts or the radio.

Regarding transmission capacity, an MP3 sound record is 1/38th the size of an HD video document with similar running time. One hour of sound devours as much information as two minutes of HD video.

Sound offers numerous reasonable advantages. In contrast to video, sound can be devoured while doing different things, for example, working, driving, practicing or taking care of family errands. This is a gigantic advantage to students who probably won't be given time during their workday or class timetable to finish self-study courses.

Sound is likewise more affordable to create. It doesn't require expert abilities, costly hardware, or managing lighting arrangements. With a sensibly estimated amplifier, some free or economical programming applications, and a touch of training, even individuals with no mixed media creation foundation can make the genuinely great quality sound substance. Furthermore, the hole among proficient and equipped novice sound is substantially less glaring than with video.

2) Use texts but not too much of texts

Text is likewise incredible for conveying data transmission amicable microlearning by means of applications like WhatsApp and WeChat. SMS is another alternative, particularly if your crowd despite everything has "include", that isn't brilliant, telephones, however, we've seen it as not so much solid but rather more costly than informing applications.

Along these lines, if your crowd is open to perusing, don't be hesitant to utilize text and the intermittent static picture. Spare intelligent components for testing and exercises as opposed to passing on fundamental data. This guidance can even apply to circumstances where data transfer capacity is not an issue. However, using too many texts can make students be bored and overwhelmed.

The third barrier is that E-Learning teaching and learning processes may cause students' to have physical problems, such as, eye strain, etc. that might make them uncomfortable during the learning process. As the user, students can adjust their visual background light of their device and their room to reduce eye strain. However, as a facilitator, teachers should give breaks as proof of the teacher's understanding and evaluation toward students' condition (Garza et. al., 2014; Narinasamy, 2018). Students can be tired by doing non-stop E-Learning activities. Eye strain and other visual Computer Visual Syndrome (CVS) can easily happen to them. In order to reduce the possibility, teachers can reduce the time of the E-Learning activity or simply by giving them breaks. Breaks for every one hour would be very helpful to help students to recover from their eye strain.

Similarly, as with all research, there are a few conditions to be offered in connection to the discoveries from the current research. Initially, the respondents to the review were totally utilized in one learning university, and in this 
way summing up to different enterprises, especially those with altogether extraordinary profiles to that of the other university ought to be attempted with care. Furthermore, the study requested that respondents remark on their latest experience of E-Learning using Google Classroom and overall respondents this may have interfaced with a scope of various kinds and configurations of the E-Learning platform experience, and they may have attempted the E-Learning at various occasions in the past. The restriction of furnishing respondents with a wide meaning of E-Learning is moreover recognized as this can prompt respondents to think about a wide scope of E-Learning draws near. Anyway, as the purpose of this research was not to concentrate on one explicit course yet on in general recognitions it was esteemed proper for the context.

\section{Conclusion}

Contemporarily, due to the COVID-19 pandemic, schools and universities are continually searching for approaches to ceaselessly build up the teaching and learning process to adapt to the situation. With this need as a key driver, numerous associations have gone to e-learning out how to facilitate this procedure of learning and teaching in an additional time-productive and safe way. Notwithstanding, while the supporters of e-learning have exhibited the advantages to be picked up by the utilization of technology in learning in such conditions, it is likewise basic to comprehend why there may be barriers from such learning approaches. The discoveries from this exploration give the point of view of the individual student and recognize the likely barriers to e-learning utilization.

This research likewise found that there are three main barriers in using E-Learning identified from a group of EFL students of UIN Malang. The three barriers are lack of personal touch in E-Learning; lack of technology and internet connectivity for both students and teachers; and physical barriers for both students and teachers, e.g., eye strain. This research also proposes the way to overcome those barriers, in which; to overcome lacking personal touch in E-Learning, the teacher must Consider the overall learning goals, Consider students' various distinctive learning styles, Offer quick feedback, Maintain more interactions; to overcome the lack of technology and internet connectivity, the teacher must try converting video material to audio, and use texts (but not too much); last but not least, to overcome the physical barriers, the teacher must give students a break while enrolling in an E-Learning activity.

However, this research covers only students' side of the house in seeing the barriers they interface during the E-Learning learning process using Google Classroom. It is highly recommended to further researchers to develop the teachers' sight on seeing the barriers in using Google Classroom as their facility in English teaching and learning process.

\section{References}

Assareh, A., \& Bidokht, M. (2011). Barriers to E-Learning.Procedia Computer Science, 791. https://doi.org/10.1016/j.procs.2010.12.129

Balanskat, A., Blamire, R., \& Kefala, S. (2006). The ICT Impact Report: A Review of Studies of ICT on Schools in Europe: European Communities. Education and Culture, 21.

Beschorner, N. (2020). Indonesia's Connectivity Challenge. Indonesia's Connectivity Challenge in Digital Connectivity Focus Group Discussion. Jakarta, Indonesia: The World Bank.

Bingimlas, K. A. (2009). Barriers to The Successful Integration of ICT in Teaching and Learning Environment: A Review of The Literature. Journal of Mathematics, Science and Technology Education, 245. https://doi.org/10.12973/ejmste/75275

Book, O. D. (2015). Oxford Dictionary. Oxford: Oxford University Press.

Burns, M. (2014, November 10). The Bandwidth Schools Have and the Bandwidth They Need. Retrieved from eLearning Industry: https://elearningindustry.com/bandwidth-schools-bandwidth-need

Cho, S., \& Berge, Z. (2002). Overcoming Barriers to Distance Training and Education. United States Distance Learning Association Journal, 231.

Clover, I. (2017). Advantages And Disadvantages Of eLearning. Retrieved from eLearning Industry: https://elearningindustry.com/advantages-and-disadvantages-of-elearning

Ertmer, P. (1999). Addressing First- and Second-Order Barriers to Change: Strategies for Technology Integration. Educational Technology Research and Development, 47(4), 47-61. https://www.jstor.org/stable/30221096?seq=1https://doi.org/10.1007/BF02299597 
Garza, R., Alejandro, E. A., Blythe, T., \& Fite, K. (2014). Caring for Students: What Teachers Have to Say. ISRN Education, 2014. http://doi.org/10.1155/2014/425856

Hadijah, S., \& Shalawati, S. (2017). Investigating Teacher 'Barrier to ICT Integration in Teaching English at Senior High School in Pekanbaru. Proceedings of ISELT FBS Universitas Negeri Padang, 302. http://ejournal.unp.ac.id/index.php/selt/article/view/8019

Haidkamp, E. (2017). 5 Tips To Create eLearning Accessible To Learners With Limited Connectivity. Retrieved from eLearning Industry: https://elearningindustry.com/create-elearning-accessible-to-learners-limited-connectivity-5-tips

Hew, K. F., \& Brush, T. (2007). Integrating Technology into K-12 Teaching and Learning. Educational Technology Research and Development, 223.https://doi.org/10.1007/s11423-006-9022-5

Janzen, M. (2014). Hot Team: Google Classroom. 67.

Kozeis, N. (2009). Impact of Computer Use on Children's Vision. Hippokratia,13(4), 230. https://www.ncbi.nlm.nih.gov/pmc/articles/PMC2776336/

Narinasamy, I. (2018). The Need to Care: Students' Perceptions of Teacher's Caring Behaviour. Conference: Asia-Pacific Network for Moral Education, At Kaohsiung Normal University, Taiwan. https://www.researchgate.net/publication/326668365

Pappas, C. (2015, November 30). 7 Tips To Create Personal Learning Paths In eLearning. Retrieved from eLearning Industry: https://elearningindustry.com/7-tips-create-personal-learning-paths-elearning

Pelgrum, W. (2001). Obstacles to The Integration of ICT in Education: Results from A Worldwide Educational Assessment. Computers \& Education, 163-178. https://doi.org/10.1016/S0360-1315(01)00045-8

Quadri, N. N., Muhammed, A., Sanober, S., Qureshi, M., \& Shah, A. (2017). Barriers Affecting Successful Implementation of E-Learning in Saudi Arabian Universities. International Journal of Emerging Technologies in Learning, 107. https://doi.org/10.3991/ijet.v12i06.7003

Schoepp, K. (2005). Barriers to Technology Integration. Learning and Teaching in Higher Education: Gulf Perspectives, 2.

Scrimshaw, R. (2004). How Can Innovative ICT Practice be Sustained and Extended? Paper presented at the Becta Research Conference.

\section{Copyrights}

Copyright for this article is retained by the author(s), with first publication rights granted to the journal.

This is an open-access article distributed under the terms and conditions of the Creative Commons Attribution license (http://creativecommons.org/licenses/by/4.0/). 